\title{
Purification and immobilization of engineered glucose dehydrogenase: a new approach to producing gluconic acid from breadwaste
}

Pinar Karagoz ${ }^{1}$, Ravneet Mandair ${ }^{1}$, Jinesh Cherukkattu Manayil², Jai Lad ${ }^{2}$, Katie Chong ${ }^{2}$, Georgios Kyriakou ${ }^{3}$, Adam F. Lee ${ }^{4}$, Karen Wilson ${ }^{4}$ and Roslyn M. Bill ${ }^{1 *}$ (D)

\begin{abstract}
Background: Platform chemicals are essential to industrial processes. Used as starting materials for the manufacture of diverse products, their cheap availability and efficient sourcing are an industrial requirement. Increasing concerns about the depletion of natural resources and growing environmental consciousness have led to a focus on the economics and ecological viability of bio-based platform chemical production. Contemporary approaches include the use of immobilized enzymes that can be harnessed to produce high-value chemicals from waste.

Results: In this study, an engineered glucose dehydrogenase (GDH) was optimized for gluconic acid (GA) production. Sulfolobus solfataricus GDH was expressed in Escherichia coli. The $K_{m}$ and $V_{\max }$ values for recombinant GDH were calculated as $0.87 \mathrm{mM}$ and $5.91 \mathrm{U} / \mathrm{mg}$, respectively. Recombinant $\mathrm{GDH}$ was immobilized on a hierarchically porous silica support (MM-SBA-15) and its activity was compared with GDH immobilized on three commercially available supports. MM-SBA-15 showed significantly higher immobilization efficiency (>98\%) than the commercial supports. After 5 cycles, GDH activity was at least 14\% greater than the remaining activity on commercial supports. Glucose in bread waste hydrolysate was converted to GA by free-state and immobilized GDH. After the 10th reuse cycle on MMSBA-15, a 22\% conversion yield was observed, generating $25 \mathrm{gGA} / \mathrm{gGDH}$. The highest GA production efficiency was $47 \mathrm{gGA} / \mathrm{gGDH}$ using free-state GDH.
\end{abstract}

Conclusions: This study demonstrates the feasibility of enzymatically converting BWH to GA: immobilizing GDH on MM-SBA-15 renders the enzyme more stable and permits its multiple reuse.

Keywords: Enzyme, Waste valorization, Recombinant protein, Immobilization

\section{Background}

The petrochemical industry continues to be an important player in the international economy [1]. In addition to fuels, petrochemical refineries produce a wide range of highly valuable platform chemicals, which are

\footnotetext{
${ }^{*}$ Correspondence: r.m.bill@aston.ac.uk

${ }^{1}$ School of Life and Health Sciences, Aston University, Birmingham B4 7ET, UK

Full list of author information is available at the end of the article
}

used in applications such as polymer, plastic, detergent, agrochemical and pharmaceutical production [2]. In response to concerns over the link between global warming and greenhouse gas emissions from these refineries [3], the production of platform chemicals from renewable resources has been identified as an attractive alternative to those derived from fossil fuels.

The bio-based production of commodities by fermentation is well-established [4-6]. However, the physiological limits of cellular production systems $(\mathrm{pH}$, temperature, 
growth inhibition by a range of compounds) are a major obstacle to their cost-competitiveness [7]. Advances in recombinant protein synthesis, purification and immobilization have allowed an alternative approach, whereby purified enzymes can be used to produce metabolites [8].

Platform chemicals are essential to industrial processes. Used as crude materials for the manufacture of diverse products, their cheap availability and efficient sourcing is a focus for modern companies [9]. Currently, the majority of platform chemicals are derived from non-renewable petroleum feedstocks. In 2004, the US Department of Energy reported a list of high-value compounds that had the potential to be derived from biomass: gluconic acid $\left(\mathrm{GA} ; \mathrm{C}_{6} \mathrm{H}_{12} \mathrm{O}_{7}\right)$ is in the top 30 high-value commodity chemicals on that list [10]. GA is a mild organic acid with an annual market volume of around 100,000 metric tonnes per year that is used in the construction, textile and pharmaceutical industries [11]. GA production via microbial fermentation processes are FDA approved and various organisms have been shown to produce this acid. Aspergillus niger and Gluconobacter oxydans, which are highly selective and efficient, have been widely used for GA production [12], but are limited to producing GA at non-toxic levels.

The hyperthermophilic archaeon, Sulfolobus solfataricus, typically grows at $80-85^{\circ} \mathrm{C}, \mathrm{pH} 2-4$ and is capable of utilizing a range of carbon sources [13]. It has been recognized that $S$. solfataricus enzymes of the Entner-Doudoroff pathway, including glucose dehydrogenase (GDH), display substrate promiscuity and therefore offer various opportunities for potential industrial applications over a range of non-physiological temperatures [14]. Proteins produced by thermophiles also tend to be more thermostable than their mesophilic counterparts because of an increased number of hydrogen and disulphide bonds, salt bridges and hydrophobic amino acids [15]. A reduced risk of microbial contamination, decreased viscosity, higher diffusion rate and mass turnover are additional advantages of working with thermophilic enzymes at higher process temperatures [16]. One specific advantage of using $\mathrm{GDH}$ over glucose oxidase (GO), which produces $\mathrm{H}_{2} \mathrm{O}_{2}$ during the oxidation of glucose to GA [17], is that no inhibitory $\mathrm{H}_{2} \mathrm{O}_{2}$ is produced. However, a challenge in the widespread industrial application of any enzyme is a lack of long-term operational stability and shelf-storage life and the difficulties of recovery and re-use [18].

Immobilization of enzymes allows their separation from the product and facilitates their recovery and re-use. Immobilization has also been used by many researchers to overcome instability problems and facilitate the repetitive use of enzymes [19-21]. Furthermore, it has the possibility to improve enzymatic efficacies due to the increase of local enzyme concentration [22]. The successful development of an immobilized enzyme process depends on the properties of the enzyme, the specific immobilization process and the properties of the support, including its morphology, composition, particle size, pore structure, specific surface area, surface functional groups and rigidity [23, 24]. Due to their robust surface chemistry and tunable morphology, porous silica supports have been extensively studied for enzyme immobilization $[25,26]$. Various immobilization methods, such as entrapment, encapsulation, self-immobilization, covalent bonding together with techniques to optimize the function of the enzyme once it has been immobilized have been described previously [27-29].

Over the last few years several advances in enzyme immobilization have been published. For example, cascade reactions have eliminated the need for the isolation and purification of reaction intermediates by controlling unfavourable or unstable intermediates [30]. The regeneration of expensive co-substrates, such as nicotinamide co-factors, is necessary for developing an economically viable process. For this purpose, co-immobilization of GDH with different enzymes such as xylose dehydrogenase [31], NADH oxidase [32], cyclohexanone monooxygenase [33], enoate reductase [34] or ketoreductase [35] has been investigated. The success of co-immobilization coupled with co-factor recycling increases the potential for GDH to be used in the production of a range of highvalue chemicals.

The aim of this study was to synthesize recombinant GDH from $S$. solfataricus and immobilize the purified enzyme onto novel support materials. Two novel, hierarchically structured silica-based supports were developed for this purpose. The activity of free-state and immobilized GDH were compared under different $\mathrm{pH}$ and temperature conditions to assess their activity. Stability, long-term storage and the re-use of immobilized GDH were investigated. To study the potential of an enzymatic approach to waste valorization, the generation of GA from bread waste hydrolysate (BWH) using immobilized GDH was analysed.

\section{Results}

\section{Purity and activity of recombinant GDH}

Following affinity purification, eluted fractions containing recombinant GDH were analysed by SDS-PAGE to assess protein purity in each fraction (Fig. 1a). The purified GDH construct contained a decahistidine tag and linker and had a molecular weight of $43 \mathrm{kDa}$. The monomer could be separated via SDS-PAGE (Fig. 1a). Proteincontaining fractions were analysed by BCA, pooled and subjected to size exclusion chromatography (Fig. 1b). The peak obtained indicated that GDH was $99.83 \%$ of the total sample and that the multiple-banding on the 

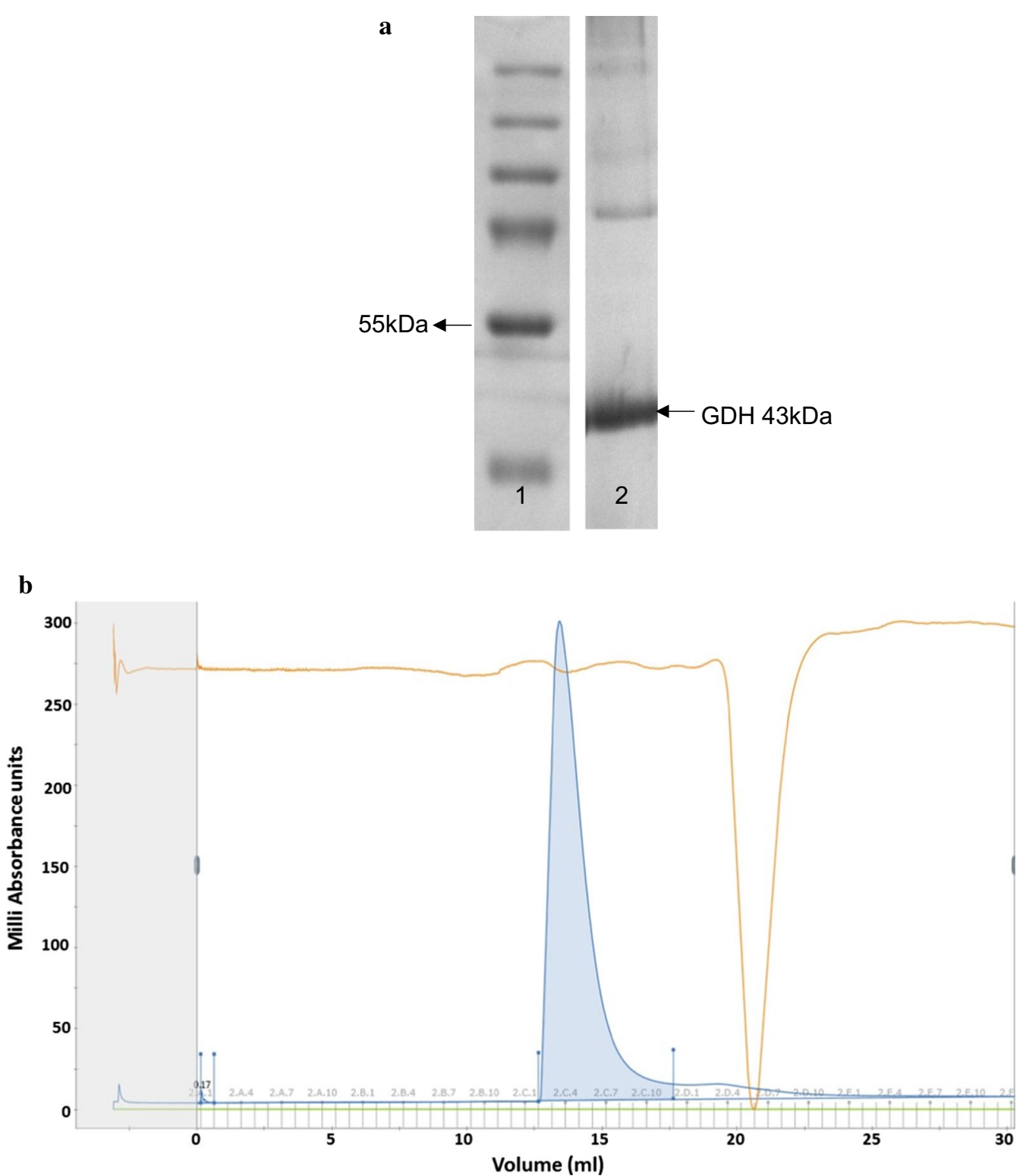

Fig. 1 a SDS-PAGE analysis of purified GDH. Lane 1 shows molecular size markers, and lane 2 is GDH purified by Ni-NTA affinity chromatography. $\mathbf{b}$ Size exclusion chromatography of GDH from lane 1 in panel (a). The blue trace represents the UV absorbance at $280 \mathrm{~nm}$ and the peak is indicative of the quantity of protein detected. The brown trace reflects the conductivity monitor which measures conductivity of buffer and samples for online monitoring of the true gradient. The green trace is applied if there is another buffer being used; since this sample was run in one buffer only, the trace has a value of 0

SDS-PAGE gel was an SDS-induced artefact. A single peak in the chromatograph was indicative of the homotetramer (Fig. 1b).

\section{Immobilization of purified GDH}

Purified GDH was immobilized onto the different support materials listed in Table 1 without the use of cross-linking agents. The hierarchical structure of macro-meso-porous structured silica-based materials used in this study is shown schematically in Fig. 2. With the introduction of macroporosity into mesoporous SBA-15 using polystyrene beads, a well-defined interconnected macro-meso network of SBA-15 is formed. The SEM analysis confirmed the formation of macromeso SBA-15 (Fig. 3a, b). The macropore diameter was consistent with the size of the polystyrene bead used in the synthesis. Mesoporous generation was further confirmed by $\mathrm{N}_{2}$ porosimetry and both MM-SBA- 15 samples 
Table 1 Specification of support materials and their immobilization efficiencies

\begin{tabular}{|c|c|c|c|c|c|c|c|}
\hline $\begin{array}{l}\text { Support } \\
\text { Material }\end{array}$ & Type of support & $\begin{array}{l}\text { Surface } \\
\text { functional } \\
\text { group }\end{array}$ & $\begin{array}{l}\text { Immobilization } \\
\text { type }\end{array}$ & $\begin{array}{l}\text { Particle size } \\
(\mu \mathrm{m})\end{array}$ & $\begin{array}{l}\text { Surface area } \\
\left(\mathrm{m}^{2} / \mathrm{g}\right)\end{array}$ & $\begin{array}{l}\text { Pore diameter } \\
(\mathrm{nm})\end{array}$ & $\begin{array}{l}\text { Immobilization } \\
\text { efficiency (\%) }\end{array}$ \\
\hline ECR8309F & $\begin{array}{l}\text { Amino C2 meth- } \\
\text { acrylate }\end{array}$ & $\begin{array}{l}\mathrm{NH}_{2} \text { (short } \\
\text { spacer) }\end{array}$ & Covalent or ionic & $150-300$ & $70-220$ & $60-120$ & $59 \pm 10$ \\
\hline ECR1090M & $\begin{array}{l}\text { Macroporous } \\
\text { styrene }\end{array}$ & None & $\begin{array}{l}\text { Adsorption/ } \\
\text { hydrophobic } \\
\text { interaction }\end{array}$ & $300-700$ & $750-850$ & $90-110$ & $76 \pm 16$ \\
\hline ECR1030M & $\begin{array}{l}\text { DVB/Meth- } \\
\text { acrylate }\end{array}$ & None & $\begin{array}{l}\text { Adsorption/ } \\
\text { hydrophobic } \\
\text { interaction }\end{array}$ & $300-700$ & $80-120$ & $20-30$ & $73 \pm 11$ \\
\hline MM-SBA-15-300 & $\begin{array}{l}\text { Hierarchical } \\
\text { porous silica }\end{array}$ & None & $\begin{array}{l}\text { Adsorption/ } \\
\text { entrapment }\end{array}$ & $100-300^{\mathrm{a}}$ & $350-380$ & $290-300\left(4.4^{b}\right)$ & $98 \pm 2$ \\
\hline MM-SBA-15-200 & $\begin{array}{l}\text { Hierarchical } \\
\text { porous silica }\end{array}$ & None & $\begin{array}{l}\text { Adsorption/ } \\
\text { entrapment }\end{array}$ & $100-300^{\mathrm{a}}$ & $270-300$ & $240-250\left(3.9^{b}\right)$ & $98 \pm 2$ \\
\hline
\end{tabular}

a Particle size determined by SEM analysis

${ }^{b}$ Mesopores determined from $\mathrm{N}_{2}$ porosimetry by BJH analysis

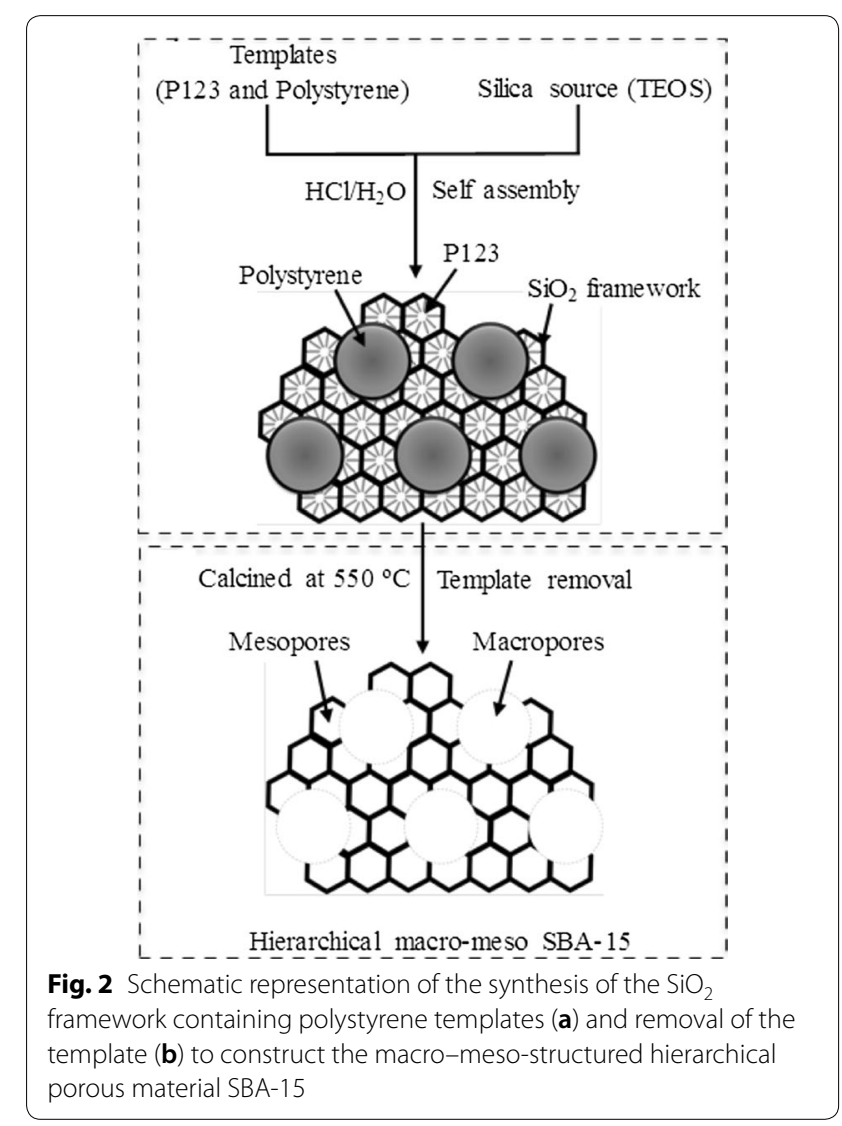

possessed surface areas of $270-380 \mathrm{~m}^{2} / \mathrm{g}$. The values were comparable with the commercial macroporous polymer support, ECR8309F, which has a slightly lower surface area of $70-220 \mathrm{~m}^{2} / \mathrm{g}$. The other commercial supports have significantly higher $\left(750-850 \mathrm{~m}^{2} / \mathrm{g}\right.$, ECR1090M) or lower $\left(80-120 \mathrm{~m}^{2} / \mathrm{g}\right.$, ECR1030M) surface areas (Table 1 ). The pore diameters of macro-meso-porous structured MM-SBA-15-300 and MM-SBA-15-200 were 2 to 10 times higher than commercial supports (ECR8309F, ECR1090M, ECR1030M). In addition, the large surface areas of MM-SBA-15-300 and MM-SBA15-200 are comparable with those of commercial supports. Under the same immobilization conditions, $3 \mathrm{mg}$ purified GDH was immobilized onto $1 \mathrm{~g}$ support. Table 1 shows that the immobilization efficiency of macro-meso-porous structured silica-based MM-SBA-15-300 and MMSBA-15-200 were significantly higher than that of all three-commercial support materials. $98 \%$ of the GDH was successfully immobilized onto MM-SBA-15 supports. SEM of immobilized GDH onto these hierarchical silica supports is shown in Fig. 3.

\section{Thermostability of free-state and immobilized GDH}

To understand the stability of GDH under non-physiological conditions, free-state and immobilized GDH were assayed at 55,65 , and $80{ }^{\circ} \mathrm{C}$ over $18 \mathrm{~h}$. The free-state and immobilized GDH were thermostable at 55 and $65{ }^{\circ} \mathrm{C}$, since no significant activity loss was detected (data not shown). The specific activity of free-state GDH at $55^{\circ} \mathrm{C}$ in $100 \mathrm{mM}$ glucose was calculated to be $2.354 \mu \mathrm{mol} / \mathrm{min} /$ $\mathrm{mg}$ (based on a 3-h reaction duration). The specific activities of immobilized GDH on ECR8309F, ECR1090M, MM-SBA-15-300 or MM-SBA-15-200 were 1.071, 1.158, $1.422,2.305$ or $2.345 \mu \mathrm{mol} / \mathrm{min} / \mathrm{mg}$ (stdev $<0.03)$, respectively. These values were set to $100 \%$ activity and activity loss was reported relative to these initial values. However, the samples heated at $80{ }^{\circ} \mathrm{C}$ for $18 \mathrm{~h}$ lost all activity. Figure 4 shows that the thermostability of GDH immobilized onto ECR8309F, an amino methacrylate support, 
a

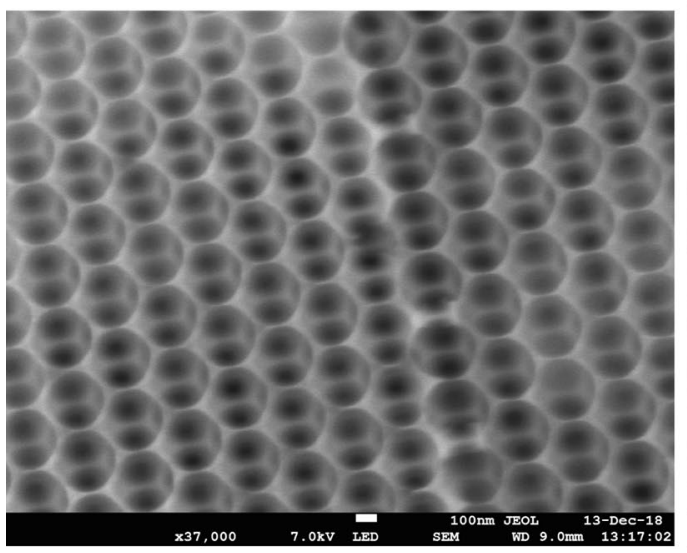

c

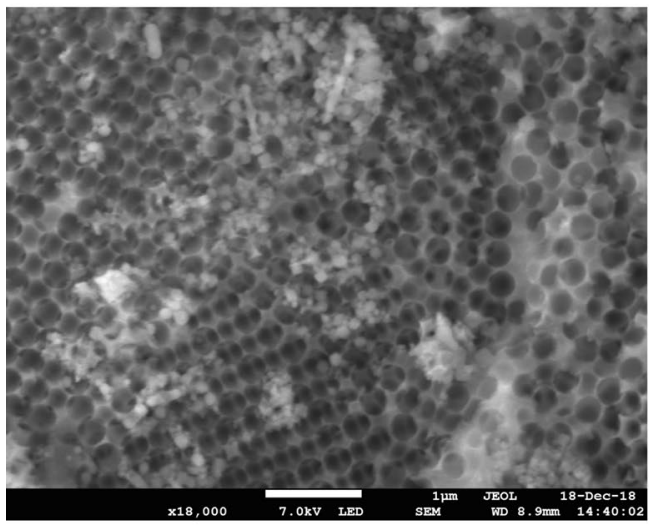

b

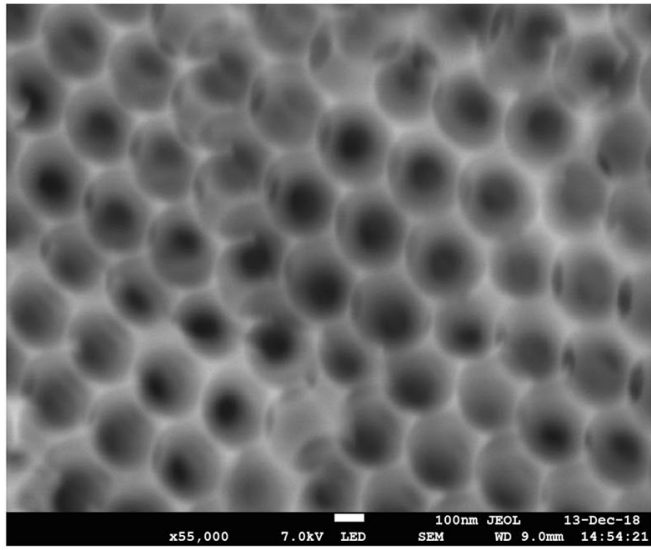

d

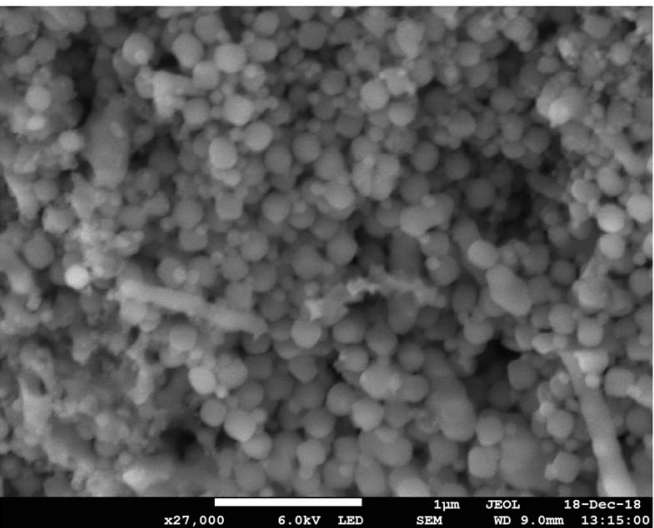

Fig. 3 SEM of hierarchical structured a MM-SBA-15-300, b MM-SBA-15-200, c GDH immobilized onto MM-SBA-15-300 and d MM-SBA-15-200

was significantly higher than the stability of free-state GDH over $60 \mathrm{~min}$. However, the thermostability of GDH immobilized onto ECR1090M or ECR1030M was not significantly increased. The thermostability of GDH immobilized onto macro-meso-structured MM-SBA-15 supports was significantly lower than GDH immobilized onto commercial supports.

\section{Re-usability of immobilized GDH}

In this study, the re-usability of purified GDH was studied over 10 cycles. As described above, activity loss was reported relative to initial values. During the first 5 cycles, the activity of GDH immobilized on macromeso-structured MM-SBA15-300 and MM-SBA15-200 was significantly more stable than GDH immobilized on commercial supports (Fig. 5). At the end of the 5th cycle, GDH immobilized on MM-SBA-15-300 and MMSBA-15-200 retained 55\% and $49 \%$ of its initial activity, respectively. The activity of GDH immobilized on ECR1090M, ECR1030M and ECR8309M were 35, 22, and $17 \%$ of initial activity, respectively.

\section{Storage stability of immobilized GDH}

To determine storage stability, free-state and immobilized GDH were stored at $4{ }^{\circ} \mathrm{C}$ for 12 weeks and the enzymatic activity was measured at various time points. Figure 6 shows that the catalytic properties of free-state GDH were well preserved at $4{ }^{\circ} \mathrm{C}$, with $90 \%$ activity being retained at the end of the 12-week storage period. However, the activity of GDH immobilized on commercial supports was significantly reduced with increasing storage time. The amount of enzyme leaking from the supports increased with time. After 8 weeks, 24.7-36.3\% of the initial protein loading had leaked from the supports and at the end of the 12-week storage period, the amount of leaked protein increased to 30-43\% (Additional file 1: Table S1). At the end of the 12-week storage period, the remaining activity of GDH immobilized onto MM-SBA-15 supports was $60 \%$ higher than that of GDH immobilized onto commercial support materials. In addition, during the 12-week storage period, the remaining activity of GDH immobilized onto silica supports showed similar characteristics to the free-state enzyme. 


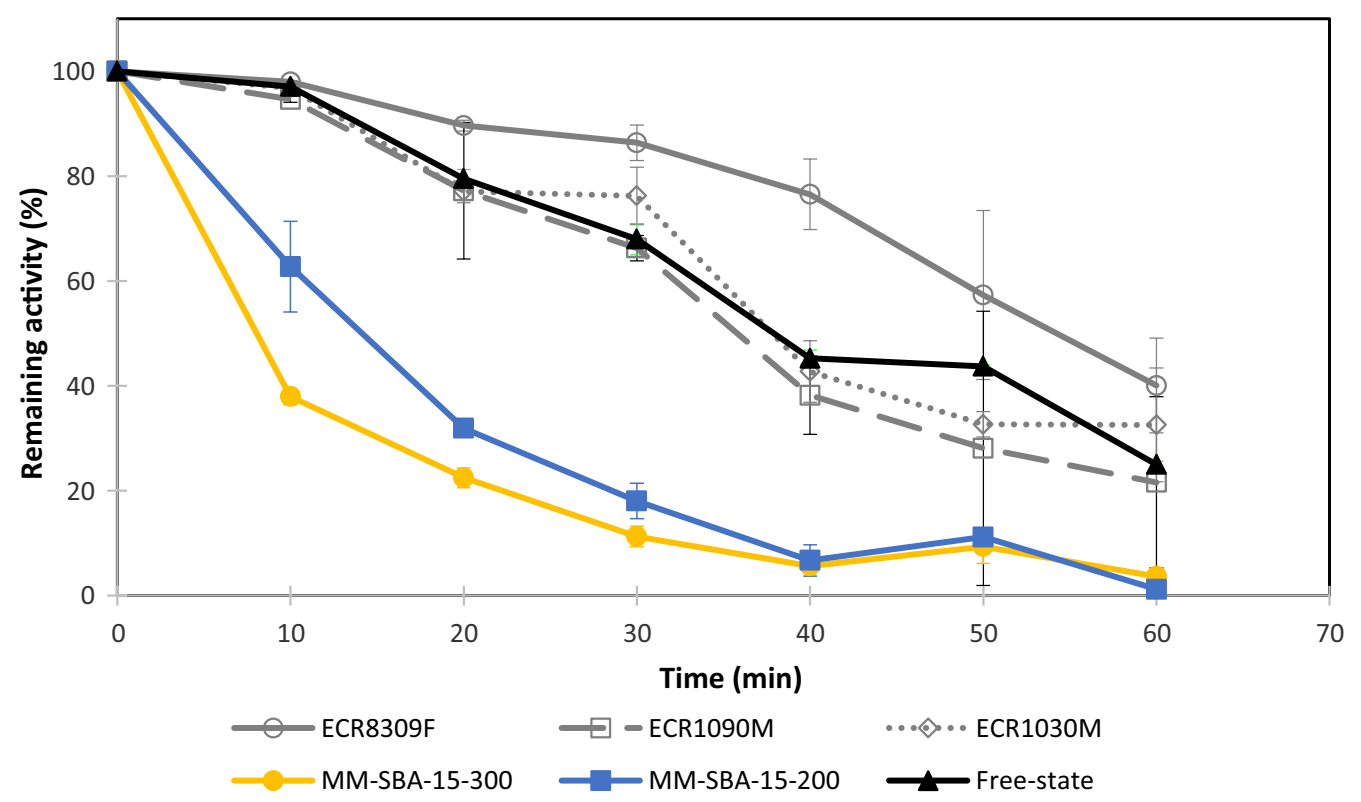

Fig. 4 Thermostability of free-state and immobilized GDH on commercial (ECR8309F, ECR1090M, ECR1030M) and hierarchical (MM-SBA-15-300 and MM-SBA-15-200) support materials at $80^{\circ} \mathrm{C}$

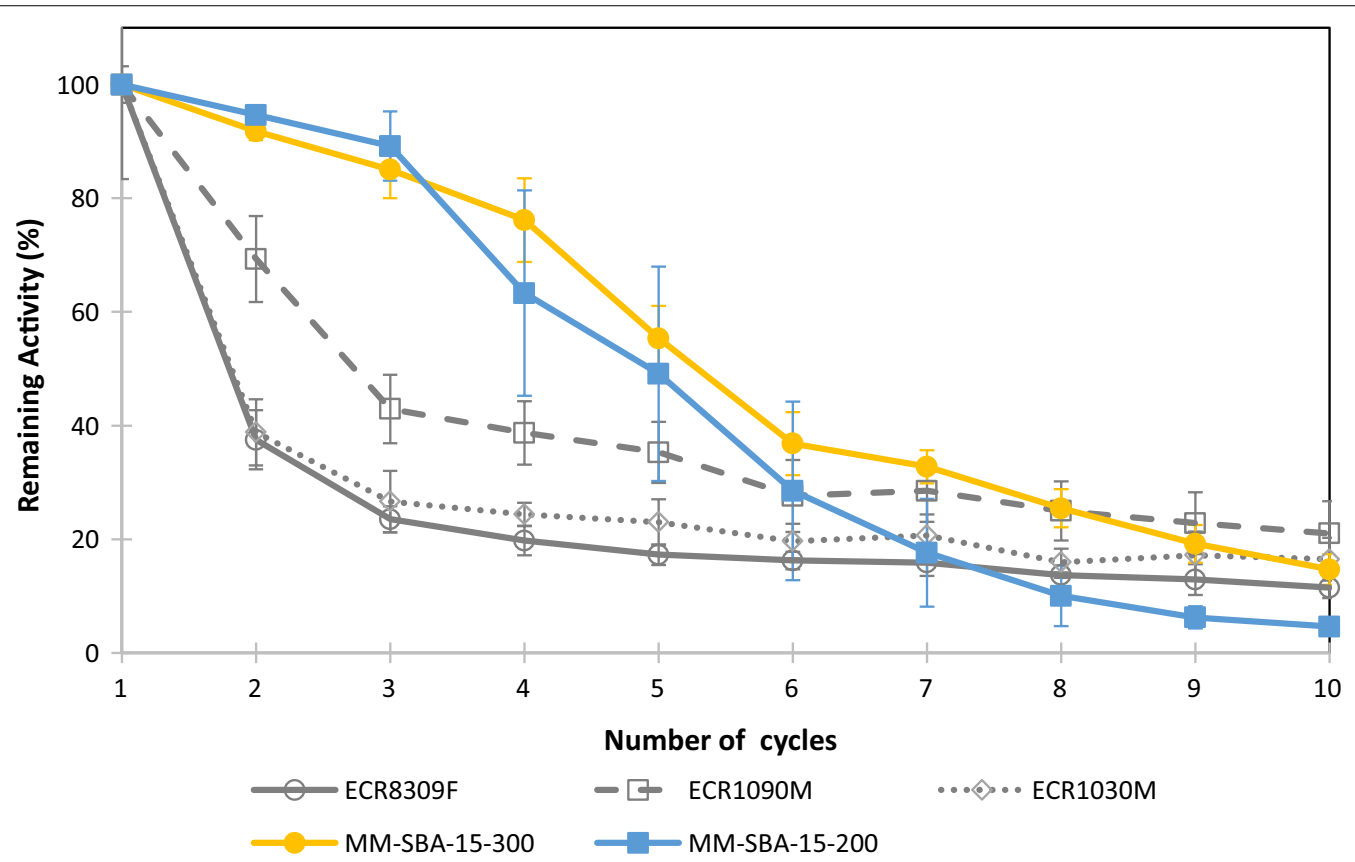

Fig. 5 Re-usability of immobilized enzyme on commercial and hierarchical supports and their loss of activity after each re-use

\section{Enzymatic activity of immobilized GDH}

The Michaelis-Menten model was used to calculate the apparent $V_{\max }$ and $K_{m}$ values of free-state GDH and GDH immobilized onto MM-SBA-15 supports (Table 2). The apparent $V_{\max }$ and $K_{m}$ values of free-state GDH were
$5.91 \mathrm{U} / \mathrm{mg}$ and $0.87 \mathrm{mM}$, respectively. After immobilization, the $V_{\max }$ values of the GDH immobilized onto MM-SBA-15-300 and MM-SBA-15-200 reduced to 0.83 and $1.14 \mathrm{U} / \mathrm{mg}$, respectively. Overall, when GDH was immobilized onto hierarchical supports, there was a five 


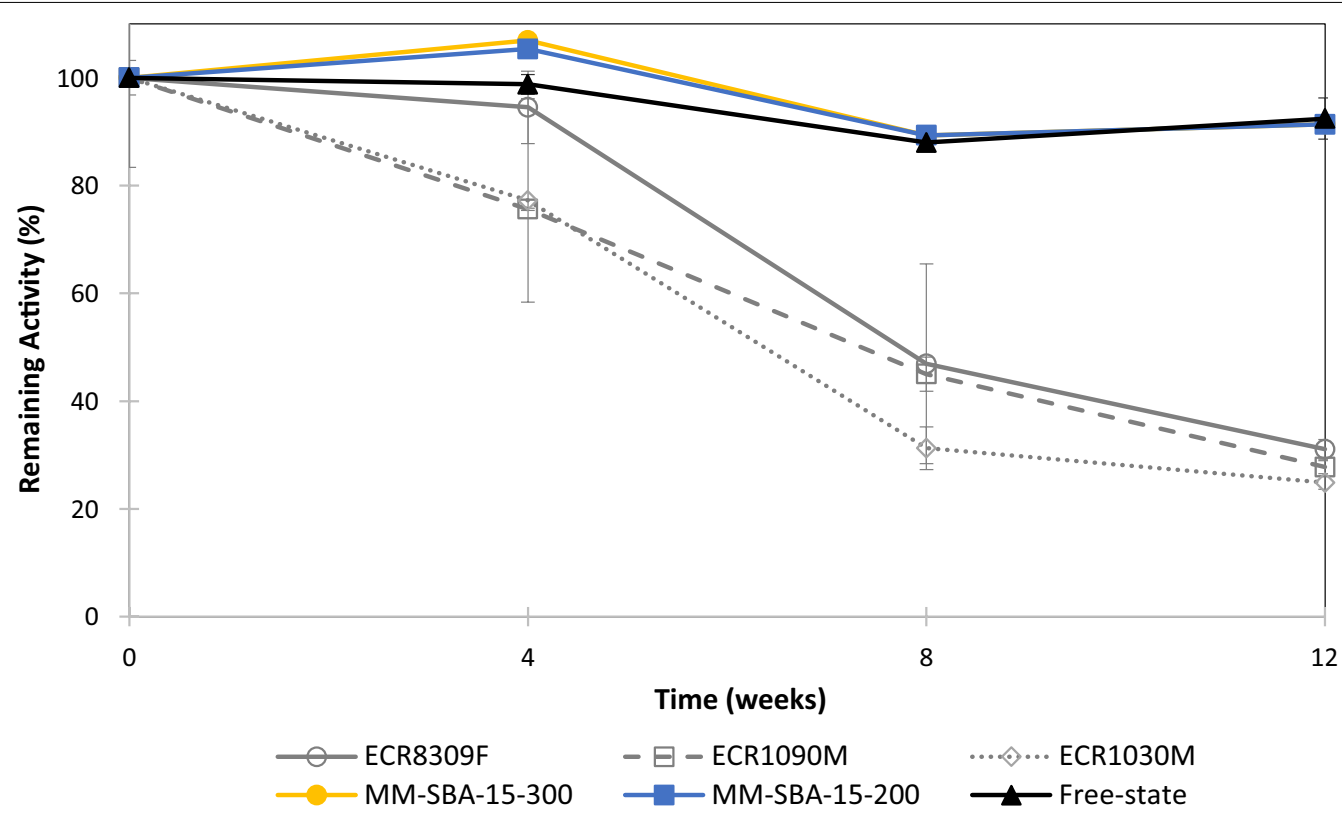

Fig. 6 Effect of the immobilization and the nature of the support material on the activity of immobilized GDH stored at $4{ }^{\circ} \mathrm{C}$ for 12 weeks

Table 2 Kinetic parameters for free-state and immobilized GDH

\begin{tabular}{llll}
\hline Kinetic parameters & Free-state & MM-SBA-15-300 & MM-SBA-15-200 \\
\hline$V_{\text {max }}(\mathrm{U} / \mathrm{mg})$ & 5.91 & 0.83 & 1.14 \\
$K_{m}(\mathrm{mM})$ & 0.87 & 1.88 & 1.22 \\
$k_{\text {cat }}(1 / \mathrm{s})$ & 3.94 & 0.55 & 0.76 \\
\hline
\end{tabular}

to sevenfold decrease in $V_{\max }$. Compared with free-state $\mathrm{GDH}$, the $K_{m}$ values of GDH immobilized onto MMSBA-15-300 and MM-SBA-15-200 increased from 0.87 to 1.88 and $1.22 \mathrm{mM}$, respectively. Compared to the freestate enzyme and the enzyme immobilized onto MMSBA-15-200, higher $K_{m}$ values were observed for GDH immobilized onto MM-SBA-15-300.

\section{Optimum conditions for GDH immobilized on macro- meso-structured SBA supports}

The activity of GDH immobilized onto MM-SBA-15-300 and MM-SBA-15-200 was investigated at different temperature and $\mathrm{pH}$ conditions. The effect of temperature on the activity of free-state and immobilized $\mathrm{GDH}$ was investigated from 30 to $80^{\circ} \mathrm{C}$ at $\mathrm{pH} 7.4$. Free and immobilized enzyme showed optimum activity at $50-55{ }^{\circ} \mathrm{C}$ (Fig. 7a). At temperatures higher than $50{ }^{\circ} \mathrm{C}$, immobilized GDH showed better relative activity than the freestate enzyme. As shown in Fig. 7a, GDH immobilized on MM-SBA-15-300 and MM-SBA-15-200 showed similar characteristics at all temperatures. Figure $7 \mathrm{~b}$ shows the effect of $\mathrm{pH}$ on the activity of free and immobilized $\mathrm{GDH}$. The optimum $\mathrm{pH}$ for immobilized and free-state $\mathrm{GDH}$ was $\mathrm{pH}$ 7.8. At $\mathrm{pH} 7.8$, the specific activities of free-state GDH, immobilized GDH on MM-SBA-15-300 and MM-SBA-15-200 were calculated to be 25.11, 24.29, $24.08 \mu \mathrm{mol} / \mathrm{min} / \mathrm{mg}$, respectively. Even at high $\mathrm{pH}$ conditions, the activity of GDH was retained, with higher activity remaining for immobilized GDH. At $\mathrm{pH}$ 9.6, the residual activity of free-state $\mathrm{GDH}$ was $78.8 \%$, while the activity of GDH immobilized onto MM-SBA-15-300 and MM-SBA-15-200 was 93.7\% and 95.0, respectively. When the $\mathrm{pH}$ was adjusted to 10.5 , immobilized $\mathrm{GDH}$ retained half its activity, while the free-state GDH retained only $18.7 \%$ of its activity.

The effect of enzyme/support ratio on GDH immobilization onto macro-meso-structured silica supports was investigated by increasing the amount of protein during the immobilization process. Table 2 shows the immobilization efficiency and relative activity of the immobilized GDH at different enzyme loadings. Limitations in the yield of purified enzyme, meant that it was not possible to test the materials at GDH/support ratios higher than 25/1, mg/g. As shown in Table 3, almost $100 \%$ of the GDH was successfully immobilized when the GDH/ support ratio was between $1 / 1$ and $5 / 1$. After this point, immobilization efficiency slightly decreased to $98 \%$ and 82\% for MM-SBA-15-300 and MM-SBA-15-200, respectively. However, the relative activity of the immobilized GDH increased until the GDH/support ratio reached 5/1. When MM-SBA-15-300 was used as a support, suitable 
a

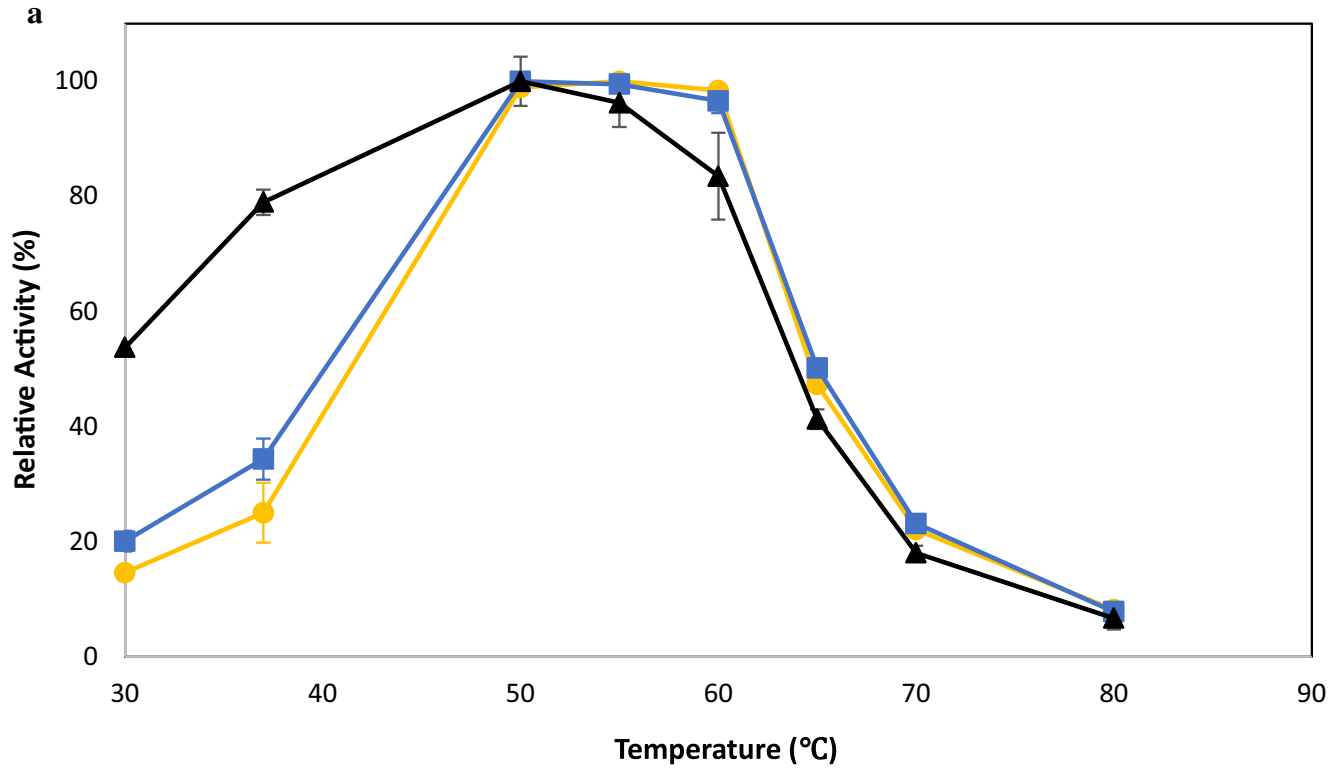

$\longrightarrow$ MM-SBA-15-300 $\rightarrow$ MM-SBA-15-200 $\longrightarrow$ Free-state

b

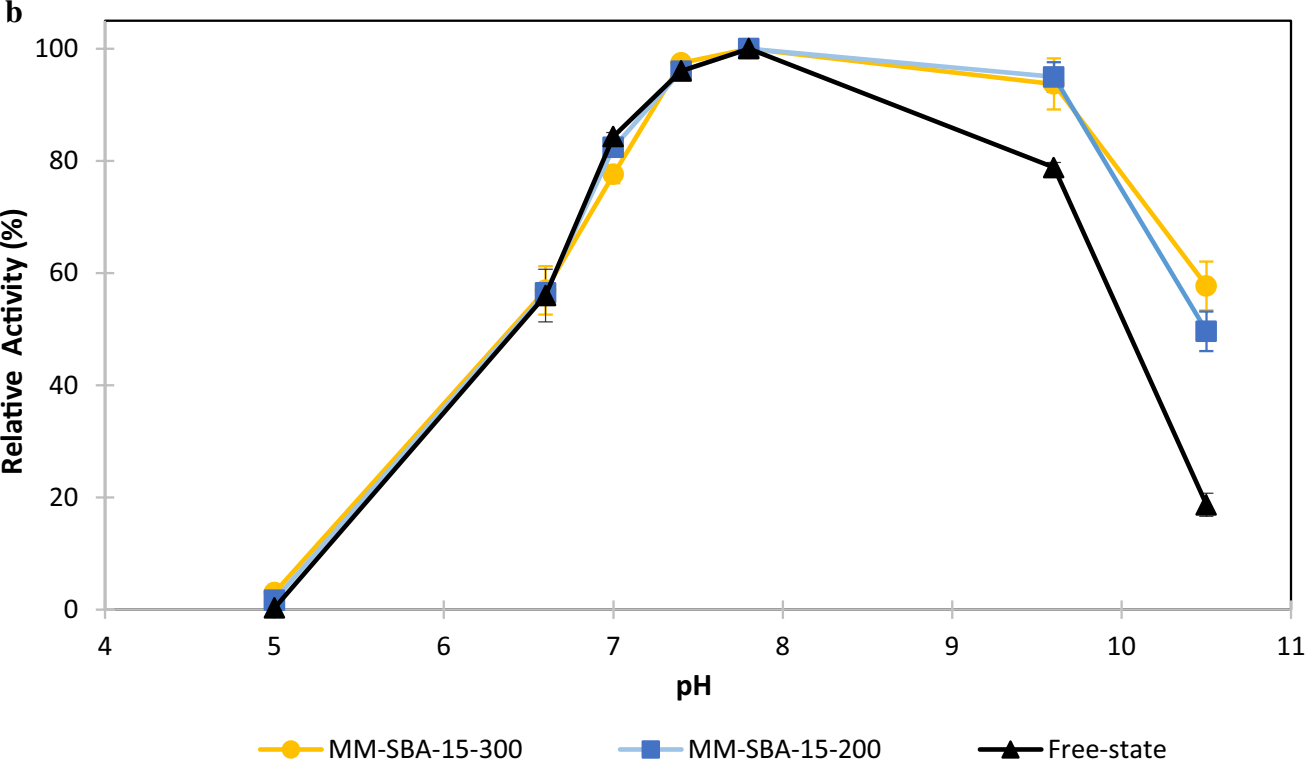

Fig. 7 Effect of $\mathbf{a}$ temperature and $\mathbf{b}$ pH on the activity of GDH when it is in a free-state or immobilized on MM-SBA-15-300 or MM-SBA-15-200

Table 3 Effect of enzyme/support ratio on enzyme immobilization efficiency and activity

\begin{tabular}{|c|c|c|c|c|c|c|}
\hline $\begin{array}{l}\text { GDH/support ratio } \\
(\mathrm{mg} / \mathrm{g})\end{array}$ & $1 / 1$ & $2 / 1$ & $3 / 1$ & $5 / 1$ & $10 / 1$ & $25 / 1$ \\
\hline \multicolumn{7}{|c|}{ Immobilization efficiency (\%) } \\
\hline MM-SBA-15-300 & $100 \pm 0$ & $100 \pm 0$ & $99 \pm 1$ & $96 \pm 4$ & $98 \pm 1$ & $98 \pm 1$ \\
\hline MM-SBA-15-200 & $100 \pm 0$ & $100 \pm 0$ & $99 \pm 1$ & $100 \pm 0$ & $98 \pm 1$ & $82 \pm 2$ \\
\hline \multicolumn{7}{|l|}{ Relative activity (\%) } \\
\hline MM-SBA-15-300 & $89 \pm 7$ & $91 \pm 3$ & $93 \pm 1$ & $95 \pm 1$ & $98 \pm 1$ & $99 \pm 1$ \\
\hline MM-SBA-15-200 & $64 \pm 4$ & $86 \pm 5$ & $98 \pm 2$ & $99 \pm 1$ & $99 \pm 1$ & $99 \pm 1$ \\
\hline
\end{tabular}


GDH/support ratios were between 3/1 and 25/1, which achieved high relative activity and high immobilization efficiency. Similarly, for MM-SBA-15-200, suitable GDH/ support ratios were between $3 / 1$ and 10/1.

\section{Conversion of BWH}

To investigate the stability and activity of free-state and immobilized GDH on waste-based sugars, BWH was used. BWH was prepared as described previously and the glucose concentration of BWH was $63.1 \pm 3.3 \mathrm{~g} / \mathrm{L}$. This sugar-rich liquor was used as the sole glucose source in the reaction mixture. The final glucose concentration was adjusted to $100 \mathrm{mM}$ using BWH. Figure 8 shows the remaining activity after each use of immobilized GDH and Fig. 9 shows the SEM images of the immobilized supports after the 10th cycle. After 7 cycles, the remaining activities of immobilized GDH were 64 and 55\% on MM-SBA-15-300 and MM-SBA-15-200, respectively. After this point, further use of immobilized enzymes reduced the activity to more than $50 \%$ of its initial activity. After 10 cycles, the remaining activities of GDH immobilized onto MM-SBA-15-300 and MMSBA-15-200 were reduced to 34 and 33\%, respectively. As can be seen from Table 4, 45\% of the glucose in $\mathrm{BWH}$ was converted by free-state GDH. A twofold decrease in the conversion yield was observed when immobilized GDH was used. GA production efficiencies by free-state GDH and GDH immobilized onto MM-SBA-15-300 and MM-SBA-15-200 were calculated as 47,32 and 35 gGA/gGDH, respectively. In every cycle, the GA production efficiency of the GDH immobilized onto MMSBA-15-200 was higher than MM-SBA-15-300 and after the 10th cycle, the GA production efficiency of GDH immobilized on MM-SBA-15-200 was double that of MM-SBA-15-300 (Fig. 9).

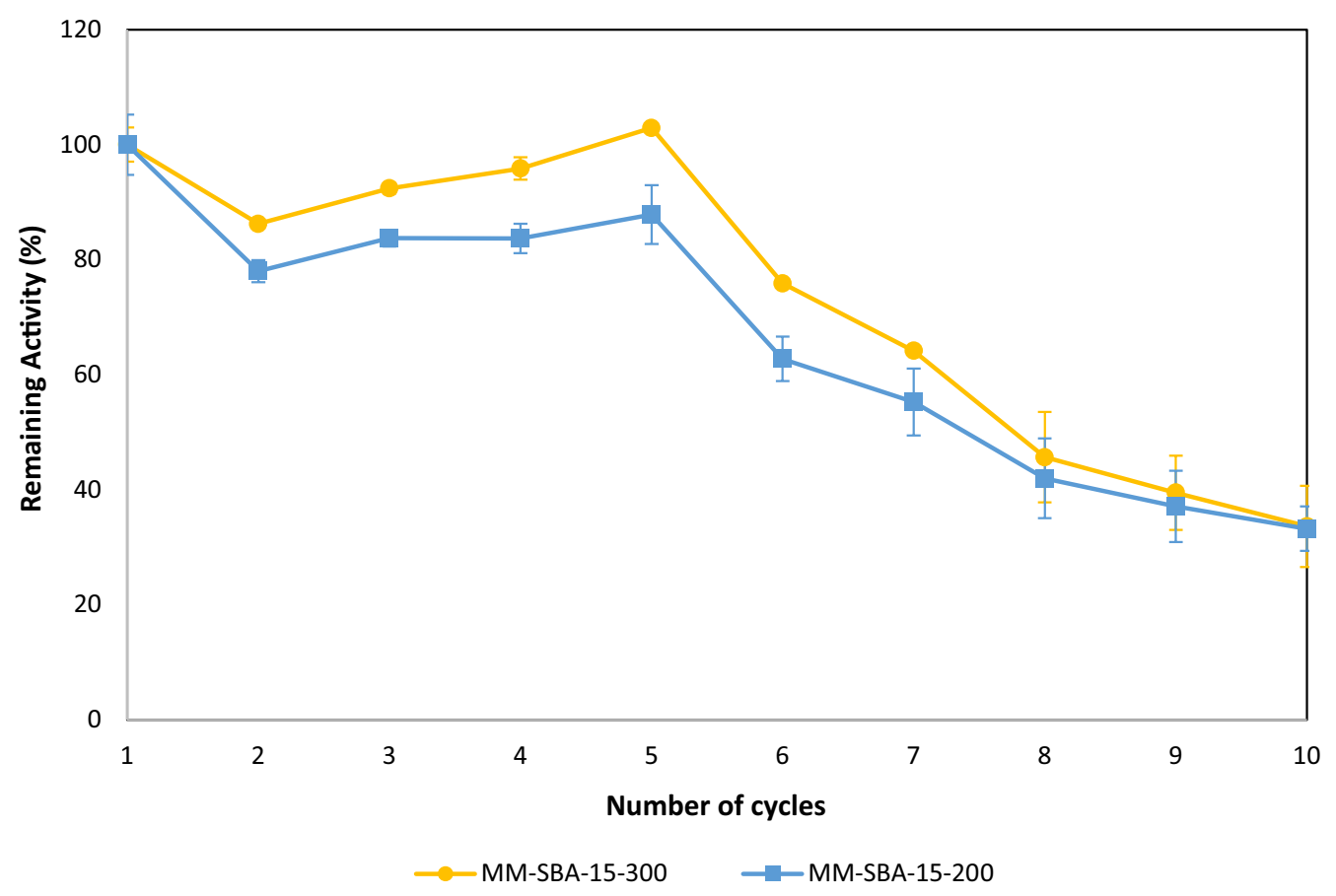

Fig. 8 Re-usability of GDH immobilized on MM-SBA-15-300 or MM-SBA-15-200 in BWH and the loss of activity after each re-use cycle

Table 4 Biocatalytic productivity of immobilized and free-state GDH on bread waste hydrolysate (BWH)

\begin{tabular}{|c|c|c|c|c|c|c|c|}
\hline Parameter & Free-state GDH & $\begin{array}{l}\text { GDH-MM- } \\
\text { SBA-15-300 } \\
\text { 1st cycle }\end{array}$ & $\begin{array}{l}\text { GDH-MM- } \\
\text { SBA-15-200 } \\
\text { 1st cycle }\end{array}$ & $\begin{array}{l}\text { GDH-MM- } \\
\text { SBA-15-300 } \\
\text { 5th cycle }\end{array}$ & $\begin{array}{l}\text { GDH-MM- } \\
\text { SBA-15-200 } \\
\text { 5th cycle }\end{array}$ & $\begin{array}{l}\text { GDH-MM- } \\
\text { SBA-15-300 } \\
\text { 10th cycle }\end{array}$ & $\begin{array}{l}\text { GDH-MM- } \\
\text { SBA-15-200 } \\
\text { 10th cycle }\end{array}$ \\
\hline Conversion of glucose in BWH (\%) & $45 \pm 8$ & $23 \pm 2$ & $25 \pm 2$ & $21 \pm 4$ & $23 \pm 3$ & $25 \pm 2$ & $22 \pm 2$ \\
\hline $\begin{array}{l}\text { Gluconic acid (GA) production } \\
\text { from BWH (gGA/gGDH) }\end{array}$ & $47 \pm 1$ & $32 \pm 1$ & $35 \pm 1$ & $31 \pm 1$ & $38 \pm 2$ & $12 \pm 1$ & $25 \pm 3$ \\
\hline
\end{tabular}


a

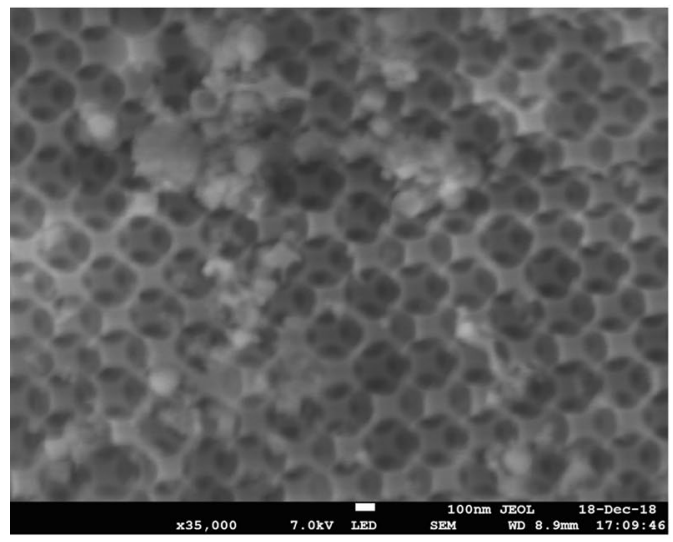

b

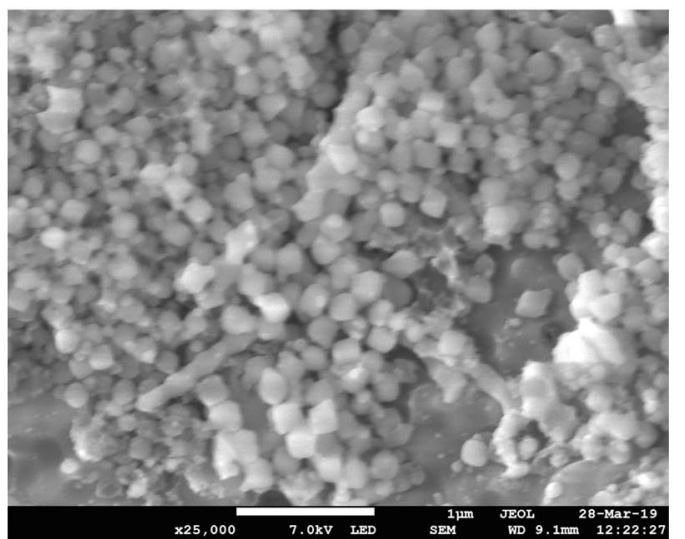

Fig. 9 SEM of immobilized GDH on a MM-SBA-15-300 or b MM-SBA-15-200 after 10 cycles

\section{Discussion}

Effective enzyme immobilization is known to be critically dependent on the choice of the support material [20] and the purity of the enzyme being immobilized: the presence of other, contaminating proteins in an enzyme preparation reduces both enzyme loading and the apparent biocatalytic performance of the enzyme. The high purity of the GDH preparation (99.83\%) achieved in this study is therefore a substantial benefit to further studies. Previous studies showed that the GDH monomer from S. solfataricus is composed of 366 amino acid residues (with a molecular weight of $41 \mathrm{kDa}$ ) and forms tetrameric assemblies in solution [14]. In addition, the crystal structure of $S$. solfataricus GDH confirmed the enzyme to be a homotetramer [36]. Our SDS-PAGE gel analysis and size exclusion chromatography data for the GDH purified in this study are consistent with this.

Due to the presence of hydroxyl groups that facilitate enzyme binding, silica-based materials are efficient and attractive supports for enzyme immobilization [31, 37] and were therefore the subject of this study. The surface area and pore diameter of an immobilization support determines its loading capacity and the size of protein that can be immobilized. Small pore sizes may limit diffusion and increase the risk of pore blockage. Furthermore, immobilization can only be achieved on the external surface of a support if the pore size is too small [38]; desorption is also more likely to occur as the operating temperature is increased [39]. It has therefore been suggested that the pore diameter should be at least four to fivefold larger than the equivalent dimension of the enzyme to be immobilized, but not so large such that it affects the mechanical properties of the support material [20]. In this study, the immobilization efficiency of GDH was significantly higher on our novel MM-SBA-15 silica support materials with macro-meso-structured hierarchical pores than on commercially available silica supports. The hierarchical supports used in this study have no functional groups on their surface, with only silanols having the potential to affect enzyme immobilization. However, the enzyme immobilization yield of the nanoporous silica used to synthesize the hierarchical supports in this study was significantly lower than MM-SBA-15 supports (Additional file 1). As a result of its relatively small macro-pore diameter, and consistent with the observations above, more immobilized enzyme was visible on the surface of MM-SBA-15-200 than MMSBA-15-300. The success of the immobilization is a result of entrapment of the enzyme inside the macro-mesostructured hierarchical pores of MM-SBA-15. Similar behaviour was reported when commercial GDH and $\mathrm{XDH}$ enzymes were co-immobilized onto hexagonal mesoporous SBA 15 [37].

The activity of an enzyme under different physicochemical conditions is a function of its stability [40]. The prevention of subunit dissociation of multimeric enzymes, such as $\mathrm{GDH}$, is an important consideration in this respect [41]. Immobilization (both physical and chemical) has been shown to be an effective strategy to address this problem [42], with previous studies demonstrating that immobilization improves the stability of multimeric enzymes [27, 36]. These findings suggest that our hierarchical silica supports may have played an important role in the prevention of subunit dissociation of the tetrameric GDH used in this study.

Immobilization often increases enzyme thermostability [43-45]. The chemistry of a support material, including the nature of its functional groups and the length of the matrix-enzyme spacer all affect thermostability [46]. In this study, we compared the thermostability 
of immobilized GDH on commercial supports and our novel hierarchically structured MM-SBA-15. We carried out thermal shocks on immobilized and free-state GDH at 55,65 , and $80^{\circ} \mathrm{C}$ overnight; no significant activity loss was detected at 55 and $65^{\circ} \mathrm{C}$. However, when the temperature was increased to $80{ }^{\circ} \mathrm{C}$, all immobilized and freestate GDH lost activity. To understand the robustness of immobilized GDH on different supports, heat shocks at $80{ }^{\circ} \mathrm{C}$ were carried out for shorter periods. Compared to free-state GDH, the thermostability of GDH immobilized on ECR8309F was significantly improved. The activity of immobilized GDH on other commercial supports had similar activities to free-state GDH. Unexpectedly, GDH immobilized on MM-SBA-15 showed reduced thermostability. This may be caused by the thermal conductance properties of silica. Similar observations have been reported in previous studies using silica-based support materials at very high temperatures [47].

Free-state enzymes are difficult to recover and re-use [34], while immobilization of enzymes allows their costeffective re-use in repeated batch or continuously running processes $[48,49]$. In this study, immobilized GDH was used 10 times. At the end of the 5th cycle, GDH immobilized on commercial supports had lost more than $65 \%$ of its initial activity. However, GDH immobilized on MM-SBA-15-300 and MM-SBA-15-200 had lost 41\% and $51 \%$ of its initial activity, respectively. The reduction of enzymatic activity after each cycle is likely caused by the leakage of unbound enzyme and/or accumulated reaction product on the surface of the material, thereby limiting the diffusion of the substrate and the product. In previous studies, commercial GDH immobilized on nanoSiO ${ }_{2}$ and SBA- 15 retained 50 and $43 \%$ of its initial activity, respectively [31], while glucose-6-phosphate dehydrogenase (G6PD) immobilized on silanized silicon retained 38\% of its initial activity after 6 cycles [50]. Improved storage stability of immobilized enzymes is another advantage over the corresponding free-state preparations [48]. The activity of GDH immobilized on commercial supports was significantly reduced over time compared with GDH immobilized on MM-SBA- 15 .

Despite the reduced thermostability of GDH on MMSBA- 15 supports at $80{ }^{\circ} \mathrm{C}$, our data demonstrated substantial enzyme activity at normal working temperatures, long-term enzyme re-usability and improved storability. To further improve the activity of GDH immobilized on MM-SBA-15, the effects of temperature and $\mathrm{pH}$ on the activity of free and immobilized GDH were tested. We noted that immobilization on MM-SBA-15 did not shift the optimum working temperature of GDH. The activity of the free-state enzyme was slightly decreased when the temperature increased from 50 to $60{ }^{\circ} \mathrm{C}$, while the activity of the immobilized enzyme was not affected. The optimum $\mathrm{pH}$ of an immobilized enzyme depends upon the particular enzyme and the chemistry of the support [51]. In this study, we tested the activity of GDH over a range of $\mathrm{pH}$. At $\mathrm{pH}$ greater than 7.5, the activity of immobilized GDH on MM-SBA-15 supports was significantly higher than free-state GDH. Usefully, at high $\mathrm{pH}$, above the $\mathrm{pK}_{\mathrm{a}}$ of GA, GA can be separated from the reaction mixture by simple separation methods, such as membrane filtration [31].

Specific area determines the loading capacity of a support and the ratio of enzyme to support material is a crucial immobilization parameter for achieving high efficiency and high reaction rates [24]. Immobilizing high concentrations of enzyme is preferable from an economical point of view [20], but increasing enzyme concentrations on the support material can also increase the cost of the process [52]. Furthermore, excessive loading may have an effect on enzyme leakage, pore blockage and mass transfer between liquid and solid [51]. Hence, working at a reasonable enzyme/support ratio is important in developing catalytic bioprocesses. In this study, we used different enzyme/support ratios and quantified immobilization efficiencies and GDH activity. At enzyme loading ratios between $1 / 1$ and $10 / 1(\mathrm{mg} / \mathrm{g})$, almost all of the GDH was immobilized onto the MM-SBA-15 supports. However, enzyme activity was reduced at decreased enzyme loading ratios, which might be a result of diffusional constraints. The highest $\mathrm{GDH} /$ support ratio tested in this study was $25 / 1(\mathrm{mg} / \mathrm{g})$ where more than $80 \%$ of the enzyme was successfully immobilized on MM-SBA-15-200. Under the same conditions, $98 \%$ of the enzyme was immobilized on MM-SBA-15-300, probably due to its higher surface area and pore diameter.

The kinetic parameters of free-state GDH and GDH immobilized on MM-SBA-15 supports showed that immobilization leads to drop in the $V_{\max }$. This expected result might be caused by mass transfer limitations [24]. As a result of enzyme attachment, some of the active sites of GDH could be blocked, which would reduce the reaction rate and $V_{\max }$ [31]. Similar observations have been made when GDH from Bacillus megaterium was immobilized on DEAE-Sephadex [53]. Diffusional limitations caused by immobilization also lead to an increase in $K_{m}$ values for GDH immobilized on MM-SBA-15 supports. As shown in Fig. 3, while GDH was mainly immobilized on the surface of MM-SBA200, GDH was predominantly immobilized inside of the pores of MM-SBA-15-300. Similarly, after immobilization of commercial GDH onto silica supports, depending of the pore structure of the supports, a reduction in $V_{\max }$ of up to 1.87 -fold, and an increase in $K_{m}$ of up to 1.78-fold were reported [31].

Increasing generation rates and quantities of food waste are a global concern $[54,55]$. Bread waste contains 
high amounts of carbohydrate that can be used as a potential feedstock in bioprocesses for the generation of various biobased products, replacing those from fossil resources with their associated economic and environmental concerns [56]. In this study, we converted bread waste to GA, a platform chemical, by using free-state and immobilized GDH. We re-used immobilized GDH 10 times in reaction mixtures containing $\mathrm{BWH}$ as a substrate. After the 7th cycle, the activity of GDH immobilized on MM-SBA-15 was above $50 \%$ of its initial activity. The GA yield from GDH immobilized on MMSBA-15-300 was higher than that on MM-SBA-15-200, in each cycle. Further investigations such as the effect of substrate levels and BWH/enzyme loading ratios on the GA production yield are needed. To develop a more effective and economic bioprocess, GDH could be coupled with an additional enzyme for co-factor recycling. In a previous study, commercial GDH was successfully co-immobilized with xylose dehydrogenase (XDH) on a silica surface for co-factor recycling [31]. In another study, commercial GDH and NADH oxidase (NOD) enzymes were immobilized on aldehyde functional ReSyn polymer microspheres for co-factor recycling [32]. In this study, we investigated an engineered GDH and the potential of hierarchical porous materials for biocatalytic applications. Co-enzyme recycling as a part of multi-enzyme cascades could be an attractive route for green chemical production from waste. However, the main focus of this study is to investigate the potential of hierarchical supports and the activity of engineered GDH when immobilized upon them. Our results show the long-term stability and the activity of engineered GDH on MM-SBA-15 supports. Potential future applications could include its coupling with other enzymes for co-factor recycling.

\section{Conclusion}

Recombinant GDH from S. solfataricus was successfully purified and immobilized onto different supports. GDH immobilized onto a novel, hierarchically structured macroporous-mesoporous silica support showed great potential for GA production from glucose as well as BWH. Hierarchically porous MM-SBA-15 showed better immobilization efficiency than commercial supports. Moreover, GDH immobilized onto these materials showed excellent reusability.

The use of GDH immobilized onto hierarchically structured supports has the potential to be incorporated into next-generation bio-refineries and waste valorization studies. GA, the product of the enzymatic process developed in this study, can be used for industrial purposes or can be converted to other high-value platform chemicals such as malic acid. Co-immobilization of the GDH produced in this study with related enzymes to recycle the co-factor, $\mathrm{NAD}^{+}$, may help develop attractive processes for more efficient platform chemical production.

\section{Materials and methods \\ Microorganisms and enzyme production}

The GDH gene from S. solfataricus was cloned into the expression vector pET30a using NdeI and BamHI as the $5^{\prime}$ and $3^{\prime}$ restriction sites, respectively. The full-length gene was synthesized by GenScript with sequence optimized for expression in E. coli and the vector was transformed into BL21-DE3 competent cells. Cells were grown in LB media supplemented with $50 \mu \mathrm{g} / \mathrm{mL}$ kanamycin and grown at $37{ }^{\circ} \mathrm{C}$ and $220 \mathrm{rpm}$ to $A_{600}=0.6 .1 \mathrm{mM}$ (final concentration) IPTG was then added and the cells were grown at room temperature for $18 \mathrm{~h}$ at $220 \mathrm{rpm}$. Cells pellets were collected by centrifugation and re-suspended in a solution containing $100 \mathrm{mM}$ HEPES pH 7.4, $200 \mathrm{mM} \mathrm{MgCl}, 10 \%$ glycerol. Cell lysates were prepared using a cell disruptor system (Bandelin, SONOPULS) and heat treated at $70{ }^{\circ} \mathrm{C}$. Cellular debris was removed by centrifugation and the crude lysate was bound overnight to Ni-NTA resin (Qiagen) and eluted with buffer containing $600 \mathrm{mM}$ imidazole, $100 \mathrm{mM}$ HEPES $\mathrm{pH}$ 7.4, $200 \mathrm{mM}$ $\mathrm{MgCl}_{2}, 10 \%$ glycerol. The protein was then dialysed into $100 \mathrm{mM}$ HEPES pH 7.4, $200 \mathrm{mM} \mathrm{MgCl}_{2}, 10 \%$ glycerol. Size exclusion chromatography was carried out on an ÄKTA Pure chromatography system (GE) using a Super$\operatorname{dex}^{\mathrm{TM}}$ Increase $10 \times 300 \mathrm{GL}$ column. Fractions containing $\mathrm{GDH}$ were pooled and their protein concentration determined using the bicinchoninic acid assay (BCA; Reagent Compatible BCA Assay Kit, ThermoFisher Scientific) and a Nanodrop device (ThermoFisher). Samples were snap frozen in liquid nitrogen and stored at $-80^{\circ} \mathrm{C}$.

\section{GDH activity assay}

The activity of GDH was assayed in $100 \mathrm{mM}$ HEPES $\mathrm{pH}$ 7.4, 2.5\% glycerol, $30 \mathrm{mM} \mathrm{MgCl}_{2}, 100 \mathrm{mM}$ glucose, $5 \mathrm{mM}$ $\mathrm{NAD}^{+}$. Unless otherwise stated, the activity assay for both immobilized and free-state GDH was conducted in a water bath at $55^{\circ} \mathrm{C}$ for $3 \mathrm{~h}$. At the end of the assay, samples were placed into pre-cooled racks and supernatants were filtered through $0.2-\mu \mathrm{m}$ filters. The activity of GDH was detected by measuring the NADH concentrations of the supernatants with a plate reader at $340 \mathrm{~nm}$. The enzyme concentration was measured using the BCA method.

\section{Determination of kinetic constants}

The kinetic constants for free-state and immobilized GDH were determined by measuring the reaction rates at regular time intervals and different substrate levels $(0$, 
$0.1,0.5,1,2.5,5,10,25,50,100 \mathrm{mM}) . K_{m}$ and $V_{\max }$ values were calculated from Lineweaver-Burk plots.

\section{Support materials}

To immobilize GDH, three different commercial enzyme supports; methacrylate-based ECR8309F, styrene-based ECR1090M and methacrylate/divinylbenzene-based ECR1030M were purchased from Purolite, UK. Mesomacroporous SBA-15 (MM-SBA-15) was synthesized via a modified true liquid crystal templated (TLCT) SBA-15 synthesis [57] which included a hard macropore template of polystyrene spheres. Polystyrene spheres were synthesized as reported elsewhere [58]. The structure-directing template (Pluronic P123l; $2 \mathrm{~mL}$ ) was mixed with hydrochloric acid acidified water $(\sim \mathrm{pH} 2,2.1 \mathrm{~mL})$ and sonicated at $40{ }^{\circ} \mathrm{C}$ to produce a homogeneous gel. The sol-gel exhibited a hexagonal mesophase. 6 g polystyrene were added to the sol-gel with stirring, resulting in the formation of a viscous solution. Tetramethoxysilane $(4 \mathrm{~mL})$ was added and mixed with stirring to form a homogeneous liquid at $40{ }^{\circ} \mathrm{C}$. The evolved methanol was removed under a light vacuum $(0.12$ bar $)$ at $40{ }^{\circ} \mathrm{C}$ to form a viscous gel overnight. The gel was exposed to the atmosphere at room temperature for $24 \mathrm{~h}$ to complete condensation before calcination at $500{ }^{\circ} \mathrm{C}$ for $6 \mathrm{~h}$ in air (ramp rate $2{ }^{\circ} \mathrm{C} /$ min). The products were designated MM-SBA-15-300 and MM-SBA-15-200, 300 and 200 according to the size of the polystyrene beads used in the synthesis. Low-angle XRD patterns were recorded on a Bruker D8 Advance diffractometer fitted with an X'celerator detector and $\mathrm{Cu}$ $\mathrm{K} \alpha(1.54 \AA)$ source over the range $2 \theta=0.3-10^{\circ}$. Nitrogen porosimetry was measured on a Quantachrome Nova 4000 porosimeter and analysed with NovaWin software. Samples were degassed at $120^{\circ} \mathrm{C}$ overnight prior to analysis at $-196{ }^{\circ} \mathrm{C}$. Brunauer-Emmett-Teller (BET) surface areas were calculated in the relative pressure range of 0.01-0.2. The Barrett-Joyner-Halenda (BJH) method was used to calculate pore diameters and pore volumes in the desorption isotherm for relative pressures $>0.35$. The polystyrene bead size and morphology of synthesized MM-SBA-15-200 and MM-SBA-15-300 were evidenced using scanning electron microscope (SEM). The characteristics of all support materials used in this study are shown in Table 1.

\section{Immobilization of GDH}

The immobilization of recombinant GDH onto different support materials was done by gently mixing the enzyme and the support material with enzyme support solution (ES; $100 \mathrm{mM}$ HEPES pH 7.4, 2.5\% glycerol, $50 \mathrm{mM}$ $\mathrm{MgCl}_{2}$ ) at room temperature for $10 \mathrm{~min}$. Unless otherwise stated, $0.03 \mathrm{mg} \mathrm{GDH}$ and $0.01 \mathrm{~g}$ support material were mixed with $1 \mathrm{~mL}$ ES. Following this, mixtures were stored at $4{ }^{\circ} \mathrm{C}$ overnight. The amount of immobilized enzyme was detected by measuring the protein concentration before and after immobilization. Immobilization yield (\%) was calculated using the equation bellow:

$$
\text { Immobilization yield }(\%)=\frac{C_{0}-C_{s}}{C_{0}} \times 100,
$$

where $C_{0}$ and $C_{S}$ denote the amount of enzyme before and after immobilization (mg), respectively.

\section{Thermal stability of free-state and immobilized GDH}

The thermal stability of free-state and immobilized GDH was investigated at 55,65 and $80{ }^{\circ} \mathrm{C}$ after $1,3,18$ and 24 h. $0.03 \mathrm{mg}$ free-state or immobilized GDH in $500 \mu \mathrm{L}$ ES were incubated as required, instantly cooled down on ice for $2 \mathrm{~min}$ and stored at $4{ }^{\circ} \mathrm{C}$ for $20 \mathrm{~min}$. Cooled samples were gently mixed with assay mixture and the activities of free and immobilized GDH were evaluated as described above.

\section{Reusability of immobilized GDH}

To detect the reusability of GDH immobilized onto different supports, the immobilized enzyme was washed with ES after each use and stored at $4{ }^{\circ} \mathrm{C}$ overnight and then re-suspended in fresh assay mixture to determine remaining activity. This procedure was repeated 10 times. The activity of the enzyme in the first cycle was defined as $100 \%$ and the remaining activities were calculated as follows:

$$
\text { Remaining activity }(\%)=\frac{a_{x_{2} \ldots 10}}{a_{1}} \times 100,
$$

where $a_{1}$ and $a_{X 2 \ldots 10}$ denote the enzyme activity at the end of the first and subsequent cycles, respectively.

\section{Effect of immobilization on storage stability}

The free-state and immobilized GDH were stored at $4{ }^{\circ} \mathrm{C}$ to detect the effect of the support material and immobilization on their storage stability. The activity of the GDH was determined at 4-week time intervals.

\section{Determination of optimum temperature and $\mathrm{pH}$}

The activity profiles were studied at different temperatures $\left(30-80^{\circ} \mathrm{C}\right)$ and $\mathrm{pH}$ ranges $(5.0-10.5)$. The $\mathrm{pH}$ of the $\mathrm{GDH}$ assay buffer was adjusted using $3 \mathrm{M} \mathrm{HCl}, 1 \mathrm{M}$ and $100 \mathrm{mM} \mathrm{NaOH}$.

\section{Preparation of bread waste hydrolysate (BWH)}

Sliced, soft white packaged bread (Warburton) was used as a feedstock. According to the manufacturer's 
nutritional information, one slice of bread (wet weight $28.8 \mathrm{~g}$ ) contained $13.1 \mathrm{~g}$ carbohydrate (of which $0.8 \mathrm{~g}$ were sugars), $2.6 \mathrm{~g}$ protein and $0.6 \mathrm{~g}$ fat. Slices were dried at $37{ }^{\circ} \mathrm{C}$ overnight and broken into small pieces by hand. Pieces from 1 slice of bread were transferred into $250-\mathrm{mL}$ Erlenmeyer flasks, $100 \mathrm{~mL}$ water was added and the flask was placed in a shaking incubator at $60{ }^{\circ} \mathrm{C}, 200 \mathrm{rpm}$ for $1 \mathrm{~h}$. As previously described [59], $5 \mathrm{mg} \alpha$-amylase from Aspergillus oryzae (Cat. No. 10065, Sigma) and $7 \mathrm{mg}$ amyloglucosidase from Rhizopus sp. (Cat. No. A9228, Sigma) were added to each flask and incubated at $60{ }^{\circ} \mathrm{C}$ for $1.5 \mathrm{~h}$. Solid particles were separated by centrifugation for $20 \mathrm{~min}$, at $4100 \times g$ and $4{ }^{\circ} \mathrm{C}$. The supernatant was transferred into a flask and autoclaved at $121{ }^{\circ} \mathrm{C}$ for $15 \mathrm{~min}$. The glucose concentration of the hydrolysate and utilization of glucose by GDH was measured using glucose assay (Cat. No. GAGO20, Sigma) and gluconic acid assay (Cat. No. MAK279, Sigma) kits. To investigate the activity and stability of free-state and immobilized GDH, $\mathrm{BWH}$ was used as the sole glucose source. The glucose concentration of the reaction mixture was set to $100 \mathrm{mM}$ using $\mathrm{BWH}$ liquor. Free and immobilized GDH were tested in $10-\mathrm{mL}$ reactions in $50 \mathrm{~mL}$ sterile Falcon tubes placed in an orbital shaker at $200 \mathrm{rpm}$ and $55^{\circ} \mathrm{C}$. Samples were taken during 3 - $\mathrm{h}$ reactions. Before measuring $\mathrm{NADH}$, glucose and GA concentrations, samples were filtered through $0.2-\mu \mathrm{m}$ filters and deproteinized using 10-kDa cut-off spin filters. As previously described, after $3 \mathrm{~h}$ the supernatant was removed and the supports with immobilized enzymes were kept in ES overnight at $4{ }^{\circ} \mathrm{C}$ and re-used in a new $\mathrm{BWH}$-containing reaction mixture 10 times.

\section{SEM analysis}

Scanning electron microscopy (SEM) images were taken using a JEOL JSM-7800F instrument equipped with EDX and operating at $10 \mathrm{kV}$. The samples were mounted using carbon tape on a sample holder. The images were also taken before and after enzyme immobilization to check the distribution of enzyme on the supports and to confirm their structural integrity.

\section{Statistical analysis}

Data were reported as the mean of at least three experiments. Error bars denote standard deviations.

\section{Supplementary information}

Supplementary information accompanies this paper at https://doi. org/10.1186/s13068-020-01735-7.

Additional file 1: Table S1. Effect of the storage period and the support material on GDH leakage.

\section{Abbreviations}

BCA: Bicinchoninic acid assay; BWH: Bread waste hydrolysate; EDX: Energydispersive X-ray analyser; ES: Enzyme support solution; GA: Gluconic acid; GDH: Glucose dehydrogenase; IPTG: Isopropyl B-D-1-thiogalactopyranoside; MM-SBA-15: Hierarchically porous silica support; SDS: Sodium dodecyl sulfate; SDS-PAGE: Sodium dodecyl sulfate-polyacrylamide gel electrophoresis; SEM: Scanning electron microscopy.

\section{Acknowledgements}

Not applicable.

\section{Authors' contributions}

RMB designed and coordinated the study with PK and RM, and together they analysed the data. JL, KC, GK, AFL and KW participated in the study design. PK performed the enzyme immobilization and activity analysis. RM synthesized and purified the enzyme. JCM prepared and characterized the support materials and performed and interpreted the SEM analysis. PK drafted the manuscript and critically revised it with RMB. All authors read and approved the final manuscript.

\section{Funding}

This research was funded by the Biotechnology and Biological Sciences Research Council (BBSRC) through the Global Challenges Research Fund Project, CAPRI-BIO (BB/P022685/1). RM is supported by a BBSRC training grant with Chemoxy Ltd (BB/M016668/1).

\section{Availability of data and materials}

Data supporting our findings can be found in Additional file 1 which has been provided as additional material.

\section{Ethics approval and consent to participate}

Not applicable.

\section{Consent for publication}

All authors have given their consent for publication.

\section{Competing interests}

The authors declare that they have no competing interests.

\section{Author details}

${ }^{1}$ School of Life and Health Sciences, Aston University, Birmingham B4 7ET, UK. ${ }^{2}$ European Bioenergy Research Institute (EBRI), Aston University, Birmingham B4 7ET, UK. ${ }^{3}$ Department of Chemical Engineering, University of Patras, 26504 Patras, Greece. ${ }^{4}$ Applied Chemistry \& Environmental Science, School of Science, RMIT University, Melbourne, VIC 3000, Australia.

Received: 27 March 2020 Accepted: 18 May 2020

Published online: 03 June 2020

\section{References}

1. Tong R, Yang Y, Shao G, Zhang Y, Dou S, Jiang W. Emission sources and probalistic health risk of volatile organic compounds emitted from production areas in a petrochemical refinery in Haian China. Human Ecol Risk Assess. 2019. https://doi.org/10.1080/10807039.2019.1579049.

2. Clews RJ. Chapter 11-The Petrochemicals Industry. In: Project Finance for the International Petroleum Industry. Academic Press; 2016. p. 187-203. https://doi.org/10.1016/B978-0-12-800158-5.00011-6.

3. Sharma A, Sharma P, Sharma A, Tyagi R, Dixit A. Hazardous effects of petrochemical industries: a review. Recent Adv Petrochem Sci. 2017;3(2):25-7.

4. Hara K, Araki M, Okai N, Wakai S, Hasunuma T, Kondo A. Development of bio-based fine chemical production through synthetic bioengineering. Microb Cell Fact. 2014;13:173.

5. Baez A, Cho K-M, Liao J. High-flux isobutanol production using engineered Escherichia coli: a bioreactor study with in situ product removal. Appl Microbiol Biotechnol. 2011;5:1681-90.

6. Blombach B, Eikmanns B. Current knowledge on isobutanol production with Escherichia coli, Bacillus subtilis and Corynebacterium glutamicum. BioengineeredBugs. 2011;2(6):346-50. 
7. Guterl J, Garbe D, Carsten J, Steffler F, Sommer B, Reiße S, Philipp A, Haack M, Rühmann B, Koltermann A, Kettling U, Brück T, Sieber V. Cell-free metabolic engineering: production of chemicals by minimized reaction cascades. Chemsuschem. 2012;5(11):2165-72.

8. Swartz J. Expanding biological applications using cell-free metabolic engineering: an overview. Metabol Eng. 2018;50:156-72.

9. Erickson B, Nelson J, Winters P. Perspective on opportunities in industrial biotechnology in renewable chemicals. Biotechnol J. 2012;7:176-85.

10. Bozell J, Petersen G. Technology development for the production of biobased products from biorefinery carbohydrates-the US Department of Energy's "Top 10" revisited. Green Chem. 2010;12(4):539-54.

11. Kirimura K, Honda Y, Hattori T. Gluconic and itaconic acids. In: Moo-Young M, editor. Comprehensive biotechnology, vol. 3. Amsterdam: Elsevier BV; 2011. p. 143-7.

12. Cañete-Rodríguezalnés A, Santos-Dueñas I, Jiménez-Hornero J, Ehrenreich A, LiebI W, Garcia-Garcia I. Gluconic acid: properties, production methods and applications - an excellent opportunity for agroindustrial by-products and waste bio-valorization. Process Biochem. 2016;51(12):1891-903

13. Grogan DW. Phenotypic characterization of the archaebacterial genus Sulfolobus: comparison of five wild-type strains. J Bacteriol 1989;171(12):6710-9. https://doi.org/10.1128/jb.171.12.6710-6719.1989

14. Lamble H, Heyer N, Bull S, Hough D, Danson M. Metabolic pathway promiscuity in the archaeon Sulfolobus solfataricus revealed by studies on glucose dehydrogenase and 2-keto-3-deoxygluconate aldolase. J Biol Chem. 2003;278(36):34066-72.

15. Gomes E, de Souza AR, Orjuela GL, Da Silva R, de Oliveira TB, Rodrigues A. Applications and benefits of thermophilic microorganisms and their enzymes for industrial biotechnology. In: Schmoll M, Dattenböck C (eds) Gene expression systems in Fungi: advancements and applications. Springer International Publishing; 2016. p. 459-492. https://doi. org/10.1007/978-3-319-27951-0_21.

16. Kambourova M. Thermostable enzymes and polysaccharides produced by thermophilic bacteria isolated from Bulgarian hot springs. Eng Life Sci. 2018;18(11):758-67.

17. Nakao K, Kiefner A, Furumoto K, Harada T. Production of gluconic acid with immobilized glucose oxidase airlift reactors. Chem Eng Sci. 1997;52:4127-33

18. Homaei A, Sariri R, Vianello F, Stevanato R. Enzyme immobilization: an update. J Chem Biol. 2013;6:185-205.

19. Gangadharan D, Nampoothiri K, Sivaramakrishnan S, Pandey A. Immobilized bacterial alpha-amylasefor effective hydrolysis of raw and soluble starch. Food Res Int. 2009;42:436-42.

20. dos Santos J, Barbosa O, Ortiz C, Berenguer-Murcia A, Rodrigues R, Fernandez-Lafuente R. Importance of the support properties for immobilization or purification of enzymes. ChemCatChem. 2015;7:2413-32.

21. Es I, Vieira J, Amaral A. Principles, techniques, and applications of biocatalyst immobilization for industrial application. Appl Microbiol Biotechnol. 2015;99(5):2065-82.

22. Ahmed I, Chang R, Tsai W-B. Poly(acrylic acid) nanogel as a substrate for cellulase immobilization for hydrolysis of cellulose. Colloids Surf B. 2017;1:339-43.

23. Hartmann M, Kostrov X. Immobilization of enzymes on porous silicasbenefits and chalenges. Chem Soc Rev. 2013;42:6277-89.

24. Patel S, Kalia V, Choi J-H, Haw J-R, Kim I-WLJ. Immobilization of laccase on $\mathrm{SiO}_{2}$ nanocarriers improves its stability and reusability. J Microbiol Biotechnol. 2014;24(5):639-47.

25. Sola-Rabada A, Sahare P, Hickman G, Vasquez M, Canham L, Perry C, Agarwal V. Biogenic porous silica and silicon sourced from Mexican Giant Horsetail (Equisetum myriochaetum) and their application as supports for enzyme immobilization. Colloids Surf B. 2018;166:195-202.

26. Wan D, Yan C, Liu Y, Zhu K, Zhang Q. A novel mesoporous nanocarrier: Integrating hollow magnetic fibrous silica with PAMAM into a single nanocomposite for enzyme immobilization. Microporous Mesoporous Mater. 2019. https://doi.org/10.1016/j.micromeso.2019.01.025.

27. Mateo C, Palomo J, Fernandez-Lorente G, Guisan J, Fernandez-Lafuente R. Improvement of enzyme activity, stability and selectivity via immobilization techniques. Enzyme Microb Technol. 2007;40:1451-63.

28. Brady D, Jordaan J. Advances in enzyme immobilization. Biotechol Lett. 2009;31:1639-50.
29. Cowan D, Fernandez-Lafuente R. Enhancing the functional properties of thermophilic enzymes by chemical modification and immobilization. Enzyme Microb Technol. 2011;49:326-46.

30. Sperl J, Sieber V. Multienzyme cascade reactions - status and recent advances. ACS Catalysis. 2018;8:2385-96.

31. Zdarta J, Pinelo M, Jesionowski T, Meyer A. Upgrading of biomass monosaccharides by immobilized glucose dehydrogenase and xylose dehydrogenase. ChemCatChem. 2018;10:1-11.

32. Twala B, Sewell B, Jordaan J. Immobilisation and characterisation of biocatalytic co-factor recycling enzymes, glucose dehydrogenase and NADH oxidase, on aldehyde functional ReSyn polymer microspheres. Enzyme Microb Technol. 2012;50:331-6.

33. Delgove MA, Valencia D, Solé J, Bernaerts KV, De Wildeman SM, Guillén M, Álvaro G. High performing immobilized Baeyer-Villiger monooxygenase and glucose dehydrogenase for the synthesis of $\varepsilon$-caprolactone derivative. Appl Catal A Gen. 2019;572:131-41.

34. Li H, Xiao W, Xie P, Zhemg L. Co-immobilization of enoate reductase with a cofactor-recycling partner enzyme. Enzyme Microb Technol. 2018;109:66-73.

35. Petrovicova T, Markosova K, Hegyi Z, Smonou I, Rosenberg M, Rebros M. Co-immobilization of ketoreductase and glucose dehydrogenase. Catalysts. 2018;8:168.

36. Milburn C, Lamble H, Theodossis A, Bull S, Hough D, Danson M, Taylor G The structural basis of substrate promiscuity in glucose dehydrogenase from the hyperthermophilic archaeon Sulfolobus solfataricus. J Biol Chem. 2006;281:14796-804.

37. Zucca P, Sanjust E. Inorganic materials as supports for covalent enzyme immobilization: methods and mechanisms. Molecules. 2014;19(9):14139-94.

38. Mohamad N, Che Marzuki N, Buang N, Huyop F, Abdul Wahab R. An overview of technologies for immobilization of enzymes and surface analysis techniques for immobilized enzymes. Biotechnol Biotechnol Equip. 2015;29(2):205-20.

39. Li Y, Gao F, Wei W, Qu J-B, Ma G-H, Zhou W-Q. Pore size of macroporous polystyrene microspheres affects lipase immobilization. J Mol Catal B Enzym. 2010. https://doi.org/10.1016/j.molcatb.2010.05.007.

40. Poorakbar E, Shaee A, Saboury A, Rad B, Khoshevisan K, Ma'mani L, Derakhshankhah H, Ganjali M, Hosseini M. Synthesis of magnetic gold mesoporous silica nanoparticles core shell forcellulase enzyme immobilization: improvement of enzymatic activity andthermal stability. Process Biochem. 2018;71:92-100

41. Bolivar J, Mateo CR-MJ, Cava F, Berebguer J, Fernandes-Lafuente R, Guisan J. The adsorption of multimeric enzymes on very lowly activated supports involves more enzyme subunits: stabilization of a glutamate dehydrogenase from Thermus thermophilus by immobilization on heterofunctional supports. Enzyme MicrobTechnol. 2009:44:139-44.

42. Fernandez-Lafuente R. Stabilization of multimeric enzymes: strategies to prevent subunit dissociation. Enzyme Microb Technol. 2009;45:405-18.

43. Kumar P, Ryan B, Henehan G. B-Glucosidase from Streptomyces griseus: nanoparticle immobilization and application to alkyl glucoside synthesis. Protein Expr Purif. 2017;132:164-70.

44. Misson M, Zhang H, Jin B. Nanobiocatalyst advancements and bioprocessing applications. R Soc Publ Interface. 2015;12:20140891.

45. Bonazza L, Manzo R, dos Santos J, Mammarella E. Operational and thermal stability analysis of thermomyces lanuginosus lipase covalently immobilized onto modified chitosan supports. Appl Biochem Biotechnol. 2018;184:182-96.

46. Zdarta J, Meyer A, Jesionowski T, Pinelo M. A general overview of support materials for enzyme immobilization: characteristics, properties, practical utility. Catalysts. 2018. https://doi.org/10.3390/catal8020092.

47. Masuda Y, Kugimiya S-I, Murai K, Hayashi A, Kato K. Enhancement of activity and stability of the formaldehyde dehydrogenase by immobilizing onto phenyl-functionalized mesoporous silica. Colloids Surf B. 2013;101:26-33.

48. Kunjukunju S, Roy A, Shekhar S, Kumta P. Cross-linked enzyme aggregates of alginate lyase: a systematic engineered approach to controlled degradation of alginate hydrogel. Int J Biol Macromol. 2018;115:176-84.

49. Yu M, Liu D, Sun L, Li J, Chen Q, Pan L, Shang J, Zhang S, Li W. Facile fabrication of $£ D$ porous hybrid sphere by co-immobilization of multienzyme directly from cell lysates as an efficient and recyclable biocatalyst 
for asymmetric reduction with co-enzyme regeneration in situ. Int J Bio Macromol. 2017;103:424-34.

50. Aissaoui N, Landoulsi J, Bergaoui L, Boujday S, Lambert J-F. Catalytic activity and thermostability of enzymes immobilized on silanized surface: influence of the crosslinking agent. Enzyme Microb Technol. 2013;52(6-7):336-43.

51. Sahin S, Ozmen I. Determination of optimum conditions for glucose6-phosphatedehydrogenase immobilization on chitosan-coated magneticnanoparticles and its characterization. J Mol Catal B Enzym. 2016;133:S25-33.

52. Fernandez-Lopez L, Pedrero S, Lopez-Carrobles N, Gorines B, Virgen-Ortiz J, Fernandez-Lafuente R. Effect of protein load on stability of immobilized enzymes. Enzyme Micro Technol. 2017;98:18-25.

53. Baron M, Fontana J, Guimaraes M, Woodward J. Stabilization and reutilization of Bacillus megaterium glucose dehydrogenase by immobilization. Appl Biochem Biotechnol. 1997:63:257-68.

54. Dahiya S, Kumar A, Sravan J, Chatterjee S, Sarkar O, Mohan S. Food waste biorefinery: sustainable strategy for circular bioeconomy. Bioresour Technol. 2018;248(Part A):2-12.

55. Maina S, Kachrimanidou V, Koutinas A. A roadmap towards a circular and sustainable bioeconomy through waste valorization. Curr Opin Green Sustain Chem. 2017:8:18-23.
56. Mirabella N, Castellani V, Sala S. Current options for the valorization of food manufacturing waste: a review. Journal of Cleaner Production. 2014:65:28-41.

57. Parlett C, Keshwalla P, Wainwright S, Bruce D, Hondow N, Wilson K, Lee A. Hierarchically ordered nanoporous Pd/SBA-15 catalyst for the aerobic selective oxidation of sterically challenging allylic alcohols. ACS Catal. 2013;3(9):2122-9.

58. Manayil J, Osatiashtiani A, Mendoza A, Parlett C, Isaacs M, Durndell L, Michailof C, Heracleous E, Lappas A, Lee A, Wilson K. Impact of macroporosity on catalytic upgrading of fast pyrolysis bio-oil by esterification over silica sulfonic acids. Chemsuschem. 2017;10(17):3506-11.

59. Benabda O, Kasmi M, Kachouri F, Hamdi M. Valorization of the powdered bread waste hydrolysate as growth medium for baker yeast. Food Bioprod Process. 2018:109:1-8.

\section{Publisher's Note}

Springer Nature remains neutral with regard to jurisdictional claims in published maps and institutional affiliations.
Ready to submit your research? Choose BMC and benefit from:

- fast, convenient online submission

- thorough peer review by experienced researchers in your field

- rapid publication on acceptance

- support for research data, including large and complex data types

- gold Open Access which fosters wider collaboration and increased citations

- maximum visibility for your research: over $100 \mathrm{M}$ website views per year

At BMC, research is always in progress.

Learn more biomedcentral.com/submissions 